\title{
2021 Handbook of Florida Water Regulation: Florida Pesticide Law ${ }^{1}$
}

\author{
Michael T. Olexa, Tatiana Borisova, and Jana Caracciolo²
}

\section{Preface}

This handbook is designed to provide an accurate, current, and authoritative summary of the principal federal and state (Florida) laws that directly or indirectly relate to agriculture. This handbook provides a basic overview of the many rights and responsibilities that farmers and farmland owners have under both federal and state laws as well as the appropriate contact information to obtain more detailed information. However, the reader should be aware that because the laws, administrative rulings, and court decisions on which this handbook is based are subject to constant revision, portions of this publication could become outdated at any time. Several details of cited laws are also left out due to space limitations. This handbook is provided as an educational text for those interested in water use and water resource issues in Florida.

This handbook is distributed with the understanding that the authors are not engaged in rendering legal or other professional advice, and the information contained herein should not be regarded as a substitute for professional advice. This handbook is not all inclusive in providing information to achieve compliance with the federal and state laws and regulations governing water protection. For these reasons, the use of these materials by any person constitutes an agreement to hold harmless the authors, the UF/IFAS Center for Agricultural and Natural Resource Law, and UF/IFAS Extension for any liability claims, damages, or expenses that may be incurred by any person as a result of reference to or reliance on the information contained in this handbook. Note: UF/IFAS is the acronym for University of Florida, Institute of Food and Agricultural Sciences.

\section{FPL Overview}

The Florida Legislature enacted the Florida Pesticide Law (FPL) to regulate the distribution, sale, and use of pesticides in Florida and to protect people and the environment from the adverse effects of pesticides, similar to the Federal Insecticide, Fungicide, and Rodenticide Act (FIFRA) (see FE588) and the federal Food Quality Protection Act (FQPA) (see FE589). To the extent that regulations under the FPL do not violate federal pesticide law, the state pesticide regulations can be more restrictive than the federal ones.

\section{Who enforces FPL?}

The FPL is administered and primarily enforced by the Florida Department of Agriculture and Consumer Services (FDACS). Under the FPL, every pesticide distributed, sold, or offered for sale within the state, or transported in intrastate commerce must be registered with FDACS and renewed annually.

1. This document is FE590, one of a series of the Food and Resource Economics Department, UF/IFAS Extension. Original publication date October 1998. Revised June 2017 and April 2021. Visit the EDIS website at https://edis.ifas.ufl.edu for the currently supported version of this publication.

2. Michael T. Olexa, professor, Food and Resource Economics Department, and director, UF/IFAS Center for Agricultural and Natural Resource Law; Tatiana Borisova, associate professor, Food and Resource Economics Department; and Jana Caracciolo, student, Levin College of Law; UF/IFAS Extension, Gainesville, FL 32611.

The Institute of Food and Agricultural Sciences (IFAS) is an Equal Opportunity Institution authorized to provide research, educational information and other services

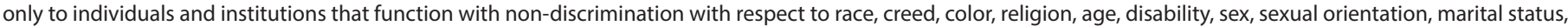

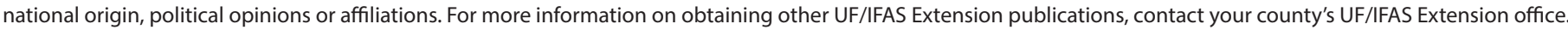
U.S. Department of Agriculture, UF/IFAS Extension Service, University of Florida, IFAS, Florida A \& M University Cooperative Extension Program, and Boards of County Commissioners Cooperating. Nick T. Place, dean for UF/IFAS Extension. 


\section{What are the duties and powers of FDACS under FPL?}

FDACS has numerous duties and powers under the FPL, including but not limited to:

- Adopting rules governing the procedures for pesticide registration and reviewing data submitted by applicants for pesticide registration

- Determining whether a pesticide should be registered, registered with conditions, or tested under field conditions in Florida

- Refusing or revoking the registration of any pesticide due to adulteration, misbranding, or other good cause, but FDACS must notify the applicant or registrant of the reason for the decision

- Requesting the EPA to require registrants of pesticides to provide FDACS with environmental test data generated in Florida or from simulations of Florida's environmental conditions

- Requesting information from the EPA relating to the findings on which the EPA based its registration determinations for pesticides registered in Florida

- Entering onto any public or private premises or carrier, during normal business hours, where pesticides are known or thought to be distributed, sold, offered for sale, stored, or applied, in performance of its duties under the FPL (no person can deny FDACS access to these premises or carrier under this condition)

- Sampling and testing pesticides that are sold, distributed, or used in Florida to determine if the pesticides or persons exercising control over the pesticides are in compliance with the FPL

\section{What is the importance of pesticide labels?}

Pesticide labels have become a central tool for enforcement of both FIFRA and state law. Under FIFRA, users must comply with all the application and precautionary instructions on the label. In this sense, the label is the law. Failure to comply with the label can result in strict penalties. It is important to note that a farmer can be penalized even if an employee of the farmer were responsible for the failure to follow the label instructions.

The FPL excuses pesticide users from following the instructions on the label only to the following extent:
- The pesticide, including a restricted-use pesticide, may be applied in lesser dosages, concentrations, or frequencies than recommended by the label

- The pesticide, including a restricted-use pesticide, may be used against a pest not specified as a target pest by the label, so long as the application is to a crop, animal, or site specified by the label, and the label does not prohibit the application

- Applicators may employ any method of application not prohibited by the labeling

- Applicators may mix the pesticide, including a restricteduse pesticide, with a fertilizer when not prohibited by the labeling

Like the EPA, FDACS has classified all pesticides, based on their active ingredient(s), as either general-use pesticides or restricted-use pesticides.

\section{What are general-use pesticides?}

General-use pesticides are pesticides that will not generally cause unreasonable adverse effects when used in accordance with its label. General-use pesticides may be applied by anyone and require no permits; however, the user must comply with labeling requirements, label instructions, and other regulations (see FE588, FIFRA).

\section{What are restricted-use pesticides?}

Restricted-use pesticides are pesticides that even when used in accordance with its label, may cause unreasonable adverse effects on the environment or injury to the applicator or other persons. The FPL restricts who may apply restricted-use pesticides to roughly the same three categories of applicators as FIFRA, only the FPL refers to these three categories as certified private applicator, certified commercial applicator, and certified public applicator. For the restrictions placed on each category of applicator, see FE588 (FIFRA). It is illegal to apply restricted-use pesticides without a certification and license.

All EPA restricted-use pesticides are incorporated into the FDACS list by reference. FDACS has also issued its own list, however, so a pesticide could conceivably be restricted in Florida while still open to general use under EPA rules. For information about pesticides classified for restricted use in Florida, see UF/IFAS site at https://edis.ifas.ufl.edu/pi140 (Why Do We Use Pesticides?).

Both FIFRA and the FPL provide for different types of licenses for private and commercial applicators of restricted-use pesticides. Generally, private applicators are 
authorized to apply pesticides to their land only. Testing and other requirements are different for private and commercial applicators. The distinction is also important with regard to license violations, as commercial applicators are subject to substantially more severe penalties than private applicators. More information about pesticide application licenses and training in Florida can be found at the FDACS website (https://www.fdacs.gov/Business-Services/ Pesticide-Licensing).

\section{What are anti-siphon requirements?}

The FPL requires that all irrigation systems that are used to administer crop management materials (e.g., pesticides and fertilizers) be equipped with anti-siphon devices to prevent the backflow of pesticide-contaminated or fertilizercontaminated water into the aquifer. These rules also apply to pesticides pre-mixed with fertilizer, although such mixtures must be clearly labeled as such before they may be offered for sale. The anti-siphon requirements also apply to water supply lines of pesticide mixing-loading equipment. The specifications for anti-siphon devices are spelled out in the rules promulgated by FDACS.

\section{What are the penalties under FPL?}

If any person, applicant, or licensee violates any provision of the FPL, FDACS may do the following:

- Deny an application for licensure

- Revoke or suspend a license

- Issue a warning letter

- Place the licensee on probation and require the licensee to attend educational classes to demonstrate competency through a written or practical examination, or to work under the direct supervision of another licensee

- Impose an administrative fee not to exceed $\$ 10,000$ for each violation

- Bring an action to enjoin the violation or threatened violation of the FPL in the circuit court of the county in which the violation occurs or is about to occur

After presenting to the court competent and substantial evidence of the violation or threatened violation, the court must immediately issue the temporary or permanent injunction sought by FDACS, without bond.

Violating any part of the FPL is a second-degree misdemeanor punishable by a fine of up to $\$ 500$ and/or up to 60 days of imprisonment. Any subsequent violation is a first-degree misdemeanor punishable by a fine of up to $\$ 1,000$ and/or up to one year of imprisonment.
Note that misdemeanors are crimes that are punishable by imprisonment of one year or less, and felonies are crimes that are punishable by imprisonment of more than one year. Misdemeanors and felonies are further classified by degrees according to the level of severity, with first degree being the most serious crimes.

\section{What is exempt from FPL?}

Exemptions from the FPL include

- The distribution, sale, and use of pesticides governed under Chapter 388 (Mosquito Control) and Chapter 482 (The Structural Pest Control Act) of the Florida Statutes

- Public officials of Florida state government and the federal government engaged in the performance of their official duties

- Pesticides or devices intended solely for export to a foreign country, and when prepared or packed according to the directions of the purchaser

- The personnel of governmental, university, or industrial research agencies only when doing applied research within a laboratory

For more information on the FPL, including the latest list of exemptions, and registration and licensing fees, contact FDACS.

\section{Sources}

Chapter 487, Florida Statutes, Sections 487.011 to 487.175

\section{Acknowledgments}

The authors are indebted to the personnel of both state and federal agencies who provided their time and advice in the preparation of this handbook. We acknowledge Carol Fountain and Susan Gildersleeve at the University of Florida for their assistance in editing this handbook. We also acknowledge funding received for updating this publication from the James S. and Dorothy F. Wershow UF/ IFAS Center for Agricultural and Natural Resource Law Endowment. 